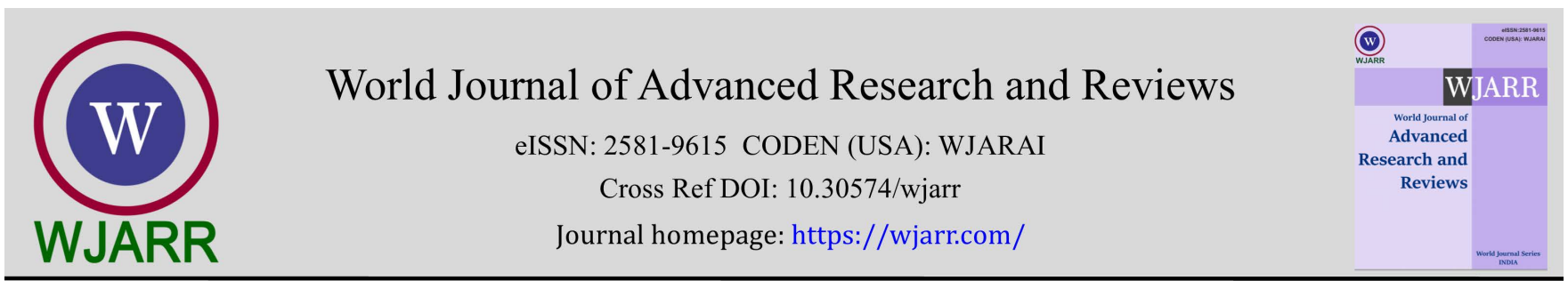

(RESEARCH ARTiClE)

\title{
Livelihood assets and socio-economic characteristics of communities to flood hazards in Central Niger Delta, Nigeria
}

\author{
Fidelis Onyekweli Agwumafa, Vincent Ezikornwor Weli *and Sunday Olatunde Eludoyin \\ Department of Geography and Environmental Management, University of Port Harcourt, Port Harcourt, Nigeria.
}

World Journal of Advanced Research and Reviews, 2021, 11(03), 009-022

Publication history: Received on 21 July 2021; revised on 29 August 2021; accepted on 31 August 2021

Article DOI: https://doi.org/10.30574/wjarr.2021.11.3.0408

\begin{abstract}
The study examined the livelihood assets and socio-economic characteristics of communities to flood hazards In Niger Delta, Nigeria. The population of the study consists of communities impacted by flood within the Niger Delta States. Purposive and random sampling methods were adopted in selecting the sample size of the respondents for this study as three of those most vulnerable Local Government Areas are selected. A self-designed instruments titled "Livelihood Assets and Socio-economic Characteristics of Communities" were used for data collection. Face and content validities of the instruments were ensured. Its instrument consists of 10-item while grand mean statistics was used to test the null hypotheses at 0.05 level of significance. The study found among others that considering the various factors that may have contributed to flooding residents' strategy to mitigate and survive its effects are imminent. Actions to control and/or cope with the factors that are mainly responsible for flooding in the study area are more than necessary in order to save human lives and forestall loss of properties to flood ravage. Based on the findings, the study recommended that massive campaign against improper dumping of refuse and public awareness of flood risks should be highlighted; creation of awareness among people living in disaster-prone areas of the risk they face and how best to respond when it occurs can be done to enhance local people's confidence and empower them to act when faced with danger and there should be policies that target the marginalized in society, such as women, children, elderly, or the poor otherwise these groups will remain most vulnerable.
\end{abstract}

Keywords: Livelihood; Socio-economic; Flood hazards; Central Niger Delta; Nigeria

\section{Introduction}

Flood is considered to be one of the most devastating and frequently occurring natural hazards in the world. Impacts of flood disaster on the society and its effect on sustainable development are overwhelming in recent years. The increasing climate change, accompanied with excessive rainfalls and its devastating consequences remain indelible in the lives of many people and the environment [1]. Over the years and in almost every part of the world, excessive rainfall due to climate change have resulted in flooding, which has claimed lives and properties. These unpalatable experiences have placed many countries, on hold in their struggle for development. As the world's population increase at an alarming rate with increase in infrastructural development on the rise, more lives and properties are becoming vulnerable to the risk of flood hazards whenever extreme events occur [2], [3]. The devastating effects are recorded in terms of mortality and economic risk by both national and international agencies. Although research claims that the mortality rate is reducing globally due to the established early warning systems in some countries (mostly the developed), but in some localities, especially in the developing and under developed countries, those living in the coastal areas, increasing deaths are witnessed because of their level of exposures and vulnerability.

\footnotetext{
* Corresponding author: Vincent Ezikornwor Weli

Department of Geography and Environmental Management, University of Port Harcourt, Port Harcourt, Nigeria. 
The severity with which flood disasters occur is on the increase in many regions of the world. Nigeria is no exception as in 2012, it experienced an unprecedented flood disaster that affected half of the 36 states including Rivers State, with 21 million people displaced; 597,476 houses destroyed or damaged; over 363 people killed and an estimated loss of USD 19.6 billion [4]

It has also been predicted that 70\% of Nigeria's 36 states are at risk from flooding in 2013 [1]. Consequently, there has been an increase in recognition by both governments and multilateral agencies of the need to mainstream flood risk reduction into development plans. Nigeria's (2003) agenda 21 document spelt out objectives to combat floods which include providing a master plan for flood control and relief measures for victims; mitigate floods through the relevant land use laws and edicts; improve institutional capacity for flood prediction and public awareness programmes and minimize the impact of floods through the provision and maintenance of appropriate infrastructure.

However, governments in Nigeria have consistently failed to systematically treat risk reduction from floods as an integrated, cross-sectoral objective. Instead, they have dealt with flood risk primarily within the very narrow framework of flood control, improved preparedness, relief and rehabilitation and preparedness capabilities and expose support to affected groups, consequently, flood hazards continue to cause great damage to infrastructure and loss of life. Furthermore, although international databases on disasters such as the database of the Centre for Research on Epidemiology of Disasters (CRED), exist, their application for vulnerability measurement is limited by the fact that the data does not give sufficient information to assess the various vulnerabilities at different spatial levels and units and also the fact that reported damages predominantly focus on direct costs and losses, often excluding indirect losses such as the long-term socio-economic impacts of a disaster [5]. Additionally, the different definitions of the categories used in these statistics, such as "affected" or "injury" are a complication when trying to make comparisons and analysis [6]. Moreover, although government disaster managers are generally aware of the propensity of many flood disaster scenarios in Rivers state and indeed Nigeria, the fact that their occurrence and consequences are often sudden, random and not well predicted creates difficulty in getting the appropriate response. This makes analysis of the vulnerability at local level necessary in order to identify weak points needing special attention during disaster situations.

Accordingly, livelihood resilience as the building block of this study is conceptualized as "the capacity of all people across generations to sustain and improve their livelihood opportunities and well-being despite environmental, economic, social, and political disturbances" [7]. Livelihood assets refer to the resource base of people. Assets are often represented as a pentagon in the Sustainable Livelihoods Framework, consisting of the following five categories: natural resources (also called 'natural capital'), physical reproducible goods ('physical capital'), monetary resources ('financial capital'), manpower with different skills ('human capital'), social networks of various kinds ('social capital') [8]. These various categories cover the following types of issues and details according [9], [10] and [11].

\subsection{Human capital}

Labour capacity, health and nutritional status, employable skills and knowledge; education; employable skills; and local employment opportunities.

\subsection{Natural capital}

Access to land, water, wildlife, flora, forest; access to common property resources (e.g. rangelands, places of worships, water reservoirs/ponds); access to agricultural inputs (e.g. seed, fertilizers, insecticides); access to irrigation infrastructure; livestock holding; and crops (staples, cash, vegetables, fruits).

\subsection{Social capital}

Refers to those stocks of social trust/status, social organizations; norms and networks that people and links with family and friends; and confidence.

\subsection{Physical capital}

Houses, vehicles, equipment/ mechanical infrastructure, livestock; water supply; housing; communications, roads, bridges and access to markets

\subsubsection{Financial capital}

Wages; individual or communal savings, gold/jewellery, access to regular income, net access to credit, insurance, and indebtedness 
A close examination of the global disaster databases from EM-DAT for the last three decades (1982-2012) revealed that climatic events (flood, storms, extreme temperature and droughts) accounts for about 69\% of total economic losses globally with flood events causing $25 \%$ of all the total losses [12]. United Nation reports a $35 \%$ increase in flood economic risks, driven by the increasing people's exposure and economic assets experienced in the last decades [12]. In Nigeria, flood accounts for the highest occurring natural hazards, with great consequences on the life and property [13]. Despite the almost yearly occurrence of flood hazards and the huge risks associated with them, it appears not much works have been done presently on livelihood, resilience and capacity assessment of communities. The present study examined the livelihood assets and socio-economic communities to flood hazards in Niger Delta regions, Nigeria.

\section{Material and methods}

The study made use of both primary and secondary sources of data. The primary data sources consist of field data collection and questionnaire administration, which was used to collect the required information from the respondents while the secondary data sources were books, both published and unpublished materials.

\subsection{Research Methodology}

Two hundred and seventy (270) respondents were selected from each state (i.e., thirty (30) from each zone and ninety (90) from each LGA) and interviewed in face-to-face interaction during a four-week period. The data for this study were collected through a questionnaire survey of household heads, key informant interviews and a focus discussion with selected representatives of various neighbourhoods. The questionnaire explores household characteristics before and after the flood disaster and their different coping mechanisms. To determine the strength of resilience of the zones, the coping strategy with the highest score at the household level was summed up and then divided by the total number of indicated coping measures in each zone to obtain an index of the relative strength of coping measures at each zone.

Table 1 Study Location from LGA and Corresponding Communities used for the study

\begin{tabular}{|c|c|c|c|c|}
\hline State & LGA & Zone 1 & Zone 2 & Zone 3 \\
\hline \multirow[t]{3}{*}{ Bayelsa State } & Sagbama & $\begin{array}{l}\text { Adagbabiri, Elemebiri and } \\
\text { Asamabiri }\end{array}$ & $\begin{array}{l}\text { Ekperiware, Igoni } \\
\text { and Anibeze }\end{array}$ & $\begin{array}{l}\text { Agbere, ofoni and } \\
\text { Agoro }\end{array}$ \\
\hline & Yenagoae & $\begin{array}{l}\text { Tombia, Agudama-Epie } \\
\text { and Igbogene }\end{array}$ & $\begin{array}{l}\text { Opolo, Azikoro and } \\
\text { Agbia }\end{array}$ & $\begin{array}{l}\text { Amarata, Biogbolo } \\
\text { and Kpansia }\end{array}$ \\
\hline & Ogbia & $\begin{array}{l}\text { Ayama, Otuobhi and } \\
\text { Emadike }\end{array}$ & $\begin{array}{l}\text { Ologoghe, Epebu and } \\
\text { Imiringi }\end{array}$ & $\begin{array}{l}\text { Opume, Olobiri and } \\
\text { Sagatama }\end{array}$ \\
\hline \multirow[t]{3}{*}{ Delta State } & Patani & $\begin{array}{l}\text { Abare, } \quad \text { Torou-Angiama } \\
\text { and Aven }\end{array}$ & $\begin{array}{l}\text { Koloware, Ogor and } \\
\text { Adobor }\end{array}$ & $\begin{array}{l}\text { Odorubu, Ebresegha } \\
\text { and Amatebe }\end{array}$ \\
\hline & Isoko South & $\begin{array}{l}\text { Akemu-Asarueha, } \\
\text { Ivrogbor-Irri and Uzere }\end{array}$ & $\begin{array}{l}\text { Araya, Odabor and } \\
\text { Umeh }\end{array}$ & $\begin{array}{l}\text { Ozoro, Emede and } \\
\text { Ikpide-Irri }\end{array}$ \\
\hline & Ndokwa East & $\begin{array}{l}\text { Iyede-Ame, Onogbokor } \\
\text { and Ibrede }\end{array}$ & $\begin{array}{l}\text { Iselegu, Ashaka and } \\
\text { Ossisa }\end{array}$ & $\begin{array}{l}\text { Abala, Utchi and } \\
\text { Aboh }\end{array}$ \\
\hline \multirow[t]{3}{*}{ Rivers State } & Ahoada East & Ubie, Ikodu and Olokuma & $\begin{array}{l}\text { Ubeta, Ula-Ubie and } \\
\text { Ebriba }\end{array}$ & $\begin{array}{l}\text { Ubtama, Owubo and } \\
\text { Odiku }\end{array}$ \\
\hline & Ahoada West & $\begin{array}{l}\text { Akinima, Udoda and } \\
\text { Igovia }\end{array}$ & $\begin{array}{l}\text { Mbiama, Okarki } \\
\text { town and Isusu }\end{array}$ & $\begin{array}{l}\text { Oshiebele, Oshi and } \\
\text { Odiereke-Ubie }\end{array}$ \\
\hline & $\begin{array}{l}\text { Ogba/Egbema } \\
\text { /Ndoni }\end{array}$ & $\begin{array}{l}\text { Ndoni, Ase-Azaga and } \\
\text { Isukwa }\end{array}$ & $\begin{array}{l}\text { Ugbaja, Akabuka and } \\
\text { Obrikom }\end{array}$ & $\begin{array}{l}\text { Erema, Ebocha and } \\
\text { Obagi }\end{array}$ \\
\hline
\end{tabular}

A risk index was calculated with the calculated coping strength of the zones and hazard occurrences using the UNDP (1992) formula: 
Summation of weighted value $(\mathrm{SWV})=$ Ranked rated value

Causes of flood index (CFI), Effectiveness of flood index (EFI) and severity of the effect of flood disaster index (SFI). To calculate the causes of flood index (CFI, EFI and SFI) we divided the Summation of weighted value (SWV) by the sum total.

\section{Results and Findings}

As presented in table 2, 34.5\% of the respondents were males and 65.5\% were Females. This study showed that the populations of the affected respondents are predominated by the females in the study area. With regards to education, research however indicated that secondary education was predominate with a frequency of 307 (39.1\%), primary 284 (36.1\%), tertiary $103(13.1 \%)$ and none formal education as $92(11.7 \%)$. Age variation of respondents as shown in the study includes 16-30, 31-45, 46-60 and >60 age bracket has a corresponding 18.7\%, 30.9\%, 39.7\% and 10.7\% respectively. The study indicates a simple majority for age bracket of $46-60$ as $39.7 \%$. Occupation of respondents shown in a descending order thus: farmers $47.3 \%$, trading/business $24.4 \%$, civil servant $17.9 \%$, self-employed $8.8 \%$ and others $1.5 \%$. Study area indicated that vast respondents are farmers and trader/business related persons. Of these said population over 578 (73.5\%) are house owners while only 208 (26.5) are tenants. However, study revealed that squatters were absent. Study reveals the monthly income of the respondents in the study area whereby it is shown that $32.7 \%$ of respondents obtained between \#10,000 and \#30,000, 26.0\% and 24.6\% for \#30,000-\#50,000 and \#50,000\#70,000 respectively. Well over 598 (76.1\%) of the respondents are above four (4) person per family size. However, just two (2) persons $0.3 \%$, three (3) persons $5.0 \%$ and four (4) persons $18.7 \%$.

Table 2 Household characteristics of Respondents

\begin{tabular}{|c|c|c|c|}
\hline Characteristics & Group & No. of respondents & Percentage \\
\hline \multirow[t]{2}{*}{ Sex } & Male & 271 & 34.5 \\
\hline & Female & 515 & 65.5 \\
\hline \multirow[t]{4}{*}{ Education } & None & 92 & 11.7 \\
\hline & Primary & 284 & 36.1 \\
\hline & Secondary & 307 & 39.1 \\
\hline & Tertiary & 103 & 13.1 \\
\hline \multirow{4}{*}{$\begin{array}{ll}\text { Age } & \text { of } \\
\text { Household } \\
\text { Heads }\end{array}$} & $16-30$ & 147 & 18.7 \\
\hline & $31-45$ & 243 & 30.9 \\
\hline & $46-60$ & 312 & 39.7 \\
\hline & $>60$ & 84 & 10.7 \\
\hline \multirow{5}{*}{$\begin{array}{l}\text { Occupation of } \\
\text { Household }\end{array}$} & Civil servant & 141 & 17.9 \\
\hline & Trader/Business & 192 & 24.4 \\
\hline & Farmer & 372 & 47.3 \\
\hline & Self Employed & 69 & 8.8 \\
\hline & Others & 12 & 1.5 \\
\hline \multirow{3}{*}{$\begin{array}{l}\text { House Owners } \\
\text { Status }\end{array}$} & Owner & 578 & 73.5 \\
\hline & Rented & 208 & 26.5 \\
\hline & Squatter & 0 & 0 \\
\hline \multirow{3}{*}{$\begin{array}{l}\text { Monthly Income } \\
\text { of Household } \\
\text { Head }\end{array}$} & $10,000-30,000$ & 257 & 32.7 \\
\hline & $30,000-50,000$ & 204 & 26.0 \\
\hline & $50,000-70,000$ & 193 & 24.6 \\
\hline
\end{tabular}




\begin{tabular}{|l|l|c|c|}
\hline & $>70,000$ & 132 & 16.8 \\
\hline \multirow{5}{*}{ Family size } & Only 2 Persons & 2 & 0.3 \\
\cline { 2 - 4 } & 3 Persons & 39 & 5.0 \\
\cline { 2 - 4 } & 4 Persons & 147 & 18.7 \\
\cline { 2 - 4 } & $>4$ & 598 & 76.1 \\
\hline & Total & & \\
\hline
\end{tabular}

\subsection{Identification of the Population of the Vulnerable Groups with respect to Socio-economic Characteristics}

Considering the various factors that may have contributed to flooding as shown in table 3 , it can be inferred that the respondents' perception on causes of vulnerabilities in the study area with the highest mean of 3.4 is nearness to river and while the least of 2.3 is poor housing structure. However, the average mean for the causes of vulnerability to flood hazards is 3.02. Causes of vulnerability with mean above the average mean value include nearness to river, land elevation, frequency of flood, flood height, access to hazard information and high rainfall. However, factors higher than the criterion of 2.5 where accepted while those below where rejected.

Table 3 Respondents' perception on causes of vulnerability to flood

\begin{tabular}{|c|c|c|c|c|c|c|c|c|c|c|c|c|}
\hline & Level of & SA & $\mathbf{A}$ & D & SD & Total & SWV & Mean & Remarks & Rank & $\mathbf{x}-\mathbf{x}^{-}$ & $\left(x-x^{-}\right)^{2}$ \\
\hline & & 4 & 3 & 2 & 1 & & & & & & & \\
\hline 1 & $\begin{array}{l}\text { Poor Drainage } \\
\text { system }\end{array}$ & 804 & 882 & 224 & 179 & 786 & 2089 & 2.7 & Accept & $9^{\text {th }}$ & $\begin{array}{c}- \\
0.32\end{array}$ & 0.1024 \\
\hline 2 & $\begin{array}{l}\text { Inadequate } \\
\text { Refuse } \\
\text { dumping }\end{array}$ & 856 & 666 & 516 & 92 & 786 & 2130 & 2.7 & Accept & $8^{\text {th }}$ & 0.32 & 0.1024 \\
\hline 3 & High Rainfall & 1192 & 822 & 396 & 16 & 786 & 2426 & 3.1 & Accept & $6^{\text {th }}$ & 0.08 & 0.0064 \\
\hline 4 & $\begin{array}{l}\text { Nearness to } \\
\text { River }\end{array}$ & 1728 & 723 & 168 & 29 & 786 & 2648 & 3.4 & Accept & $1^{\text {st }}$ & 0.38 & 0.1444 \\
\hline 5 & $\begin{array}{l}\text { Frequency of } \\
\text { Flood }\end{array}$ & 1636 & 849 & 136 & 8 & 786 & 2629 & 3.3 & Accept & $3^{\text {rd }}$ & 0.28 & 0.0784 \\
\hline 6 & $\begin{array}{ll}\text { Access } & \text { to } \\
\text { hazard } & \\
\text { information } & \\
\end{array}$ & 1096 & 976 & 372 & 34 & 786 & 2478 & 3.2 & Accept & $5^{\text {th }}$ & 0.18 & 0.0324 \\
\hline 7 & $\begin{array}{l}\text { High ratio of } \\
\text { illiteracy }\end{array}$ & 988 & 705 & 402 & 103 & 786 & 2198 & 2.8 & Accept & $7^{\text {th }}$ & 0.22 & 0.0484 \\
\hline 8 & Flood height & 1680 & 693 & 156 & 57 & 786 & 2586 & 3.3 & Accept & $4^{\text {th }}$ & 0.28 & 0.0784 \\
\hline 9 & Land elevation & 1592 & 873 & 218 & 0 & 786 & 2683 & 3.4 & Accept & $2^{\text {nd }}$ & 0.38 & 0.1444 \\
\hline 10 & $\begin{array}{l}\text { Poor housing } \\
\text { structure }\end{array}$ & 568 & 501 & 586 & 184 & 786 & 1839 & 2.3 & Reject & $10^{\text {th }}$ & $\begin{array}{c}- \\
0.72\end{array}$ & 0.5184 \\
\hline & & & & & & & & 30.2 & & & & 1.256 \\
\hline & & & & & & & & 3.02 & & & & \\
\hline
\end{tabular}

\subsection{Factors responsible for Susceptibility (Unavailability of Basic Needs)}

From table 4, it shows that the respondents' perception on unavailability of basic need in event of flooding in the study area with the highest mean is 3.5 while the least is 1.9. However, the average mean is 2.7. The range of severity of unavailability of basic needs in the event of flood disaster is 1.6. The effects with mean above the average mean are considered to be very severe in the area. Effects with high severity of unavailability of basic needs in event of flooding 
are water supply, electricity, food shortage, lack of planting materials as a result of inundation of flood and absence of storage facilities with 3.5, 3.3, 3.1, 3.0 and 2.8 respectively. However, effects higher than the criterion of 2.5 where accepted and ranked accordingly while those below where rejected.

Table 4 Factors responsible for Susceptibility (Unavailability of Basic Needs)

\begin{tabular}{|c|c|c|c|c|c|c|c|c|c|c|c|c|}
\hline & \multirow{2}{*}{$\begin{array}{l}\text { Unavailability of } \\
\text { Basic Needs }\end{array}$} & SA & A & D & SD & \multirow[t]{2}{*}{ Total } & \multirow[t]{2}{*}{ SWV } & \multirow[t]{2}{*}{ Mean } & \multirow[t]{2}{*}{ Remarks } & \multirow[t]{2}{*}{ Rank } & \multirow[t]{2}{*}{$x-x^{-}$} & \multirow[t]{2}{*}{$(x-x)^{2}$} \\
\hline & & 4 & 3 & 2 & 1 & & & & & & & \\
\hline 1 & Water Supply & 1608 & 1116 & 16 & 4 & 786 & 2744 & 3.5 & Accepted & $1^{\text {st }}$ & 0.84 & 0.7056 \\
\hline 2 & Electricity & 1568 & 804 & 220 & 16 & 786 & 2608 & 3.3 & Accepted & $2^{\text {nd }}$ & 0.64 & 0.4096 \\
\hline 3 & Tarred Road & 268 & 327 & 624 & 298 & 786 & 1517 & 1.9 & Rejected & $10^{\text {th }}$ & $\begin{array}{c}- \\
0.76 \\
\end{array}$ & 0.5776 \\
\hline 4 & Health Facilities & 264 & 594 & 562 & 241 & 786 & 1661 & 2.1 & Rejected & $9^{\text {th }}$ & $\begin{array}{c}- \\
0.56\end{array}$ & 0.3136 \\
\hline 5 & Mobility & 376 & 567 & 566 & 220 & 786 & 1729 & 2.2 & Rejected & $7^{\text {th }}$ & $-\overline{4}$ & 0.2116 \\
\hline 6 & Food shortage & 1236 & 846 & 284 & 53 & 786 & 2419 & 3.1 & Accepted & $3^{\text {rd }}$ & 0.44 & 0.1936 \\
\hline 7 & $\begin{array}{l}\text { Poor } \\
\text { accommodation }\end{array}$ & 792 & 552 & 372 & 218 & 786 & 1934 & 2.5 & Accepted & $6^{\text {th }}$ & $-\overline{1}$ & 0.0256 \\
\hline 8 & $\begin{array}{l}\text { Absence of storage } \\
\text { facilities }\end{array}$ & 1096 & 630 & 370 & 117 & 786 & 2213 & 2.8 & Accepted & $5^{\text {th }}$ & 0.14 & 0.0196 \\
\hline 9 & $\begin{array}{l}\text { Inadequate } \\
\text { communication } \\
\text { gadgets to facilitate } \\
\text { information }\end{array}$ & 568 & 396 & 458 & 283 & 786 & 1705 & 2.2 & Rejected & $8^{\text {th }}$ & 0.46 & 0.2116 \\
\hline \multirow[t]{3}{*}{10} & $\begin{array}{l}\text { Lack of planting } \\
\text { materials as a result } \\
\text { of inundation of } \\
\text { flood }\end{array}$ & 1188 & 795 & 278 & 85 & 786 & 2346 & 3.0 & Accepted & $4^{\text {th }}$ & 0.34 & 0.1156 \\
\hline & Total & & & & & & & 26.6 & & & & 2.784 \\
\hline & & & & & & & & 2.66 & & & & \\
\hline
\end{tabular}

\subsection{Examining the Types of Livelihood Assets of the Residents in the Study Area}

Study shows a wide variation in the respondent's perception on the types of livelihood assets of the respondents.

Respondents' perception on types of livelihood assets of the residents engulfed by flood as shown in table 5 in the study area has a highest mean of 3.4 is Household income while the least mean of 2.8 is quality of agricultural tools. The average mean is 3.1. However, the range of severity of flood hazard on the livelihood assets of resident is 0.6 . The effects with mean above the average mean are considered to be very severe in the area. Effects with high severity of flood hazard on types livelihood assets are household income, water resources, number of workforce (human capital) and number of livestock. However, criterion mean of 2.5 was used to either accept or reject items as well as the ranking. 
Table 5 Respondents' perception on types of Livelihood Assets of the Residents

\begin{tabular}{|c|c|c|c|c|c|c|c|c|c|c|c|c|}
\hline & \multirow{2}{*}{$\begin{array}{c}\text { Type of } \\
\text { Livelihood } \\
\text { Assets }\end{array}$} & SA & $\mathbf{A}$ & D & SD & \multirow{2}{*}{$\begin{array}{c}\text { Tota } \\
1\end{array}$} & \multirow[t]{2}{*}{ SWV } & \multirow[t]{2}{*}{ Mean } & \multirow[t]{2}{*}{ Remarks } & \multirow[t]{2}{*}{ Rank } & \multirow[t]{2}{*}{$\mathbf{x}-\mathbf{x}^{-}$} & \multirow[t]{2}{*}{$\left(x-x^{-}\right)^{2}$} \\
\hline & & 4 & 3 & 2 & 1 & & & & & & & \\
\hline 1 & $\begin{array}{l}\text { Cultivated Land } \\
\text { Area }\end{array}$ & 1224 & 753 & 336 & 61 & 786 & 2374 & 3.0 & Accepted & $6^{\text {th }}$ & -0.04 & 0.0016 \\
\hline 2 & $\begin{array}{l}\text { Quality of } \\
\text { Cultivated Land }\end{array}$ & 1068 & 867 & 344 & 58 & 786 & 2337 & 3.0 & Accepted & $8^{\text {th }}$ & -0.04 & 0.0016 \\
\hline 3 & $\begin{array}{l}\text { Quality of } \\
\text { Agricultural } \\
\text { Tools }\end{array}$ & 1028 & 822 & 258 & 126 & 786 & 2234 & 2.8 & Accepted & $10^{\text {th }}$ & -0.24 & 0.0576 \\
\hline 4 & $\begin{array}{l}\text { Number } \\
\text { Livestock }\end{array}$ & 1236 & 882 & 204 & 81 & 786 & 2403 & 3.1 & Accepted & $4^{\text {th }}$ & 0.06 & 0.0036 \\
\hline 5 & $\begin{array}{l}\text { Number of } \\
\text { Workforce } \\
\text { (Human } \\
\text { Capital) }\end{array}$ & 1324 & 657 & 396 & 38 & 786 & 2415 & 3.1 & Accepted & $3^{\text {rd }}$ & 0.06 & 0.0036 \\
\hline 6 & $\begin{array}{l}\text { Agricultural } \\
\text { Technical } \\
\text { Capacity } \\
\text { of Labourers }\end{array}$ & 964 & 1176 & 188 & 59 & 786 & 2387 & 3.0 & Accepted & $5^{\text {th }}$ & -0.04 & 0.0016 \\
\hline 7 & $\begin{array}{l}\text { Degree of } \\
\text { Neighbourhood } \\
\text { Communication } \\
\mathrm{s}\end{array}$ & 1152 & 807 & 232 & 113 & 786 & 2304 & 2.9 & Accepted & $9^{\text {th }}$ & -0.14 & 0.0196 \\
\hline 8 & $\begin{array}{l}\text { Household } \\
\text { income }\end{array}$ & 1648 & 852 & 136 & 22 & 786 & 2658 & 3.4 & Accepted & $1^{\text {st }}$ & 0.36 & 0.1296 \\
\hline 9 & $\begin{array}{l}\text { Water } \\
\text { resources }\end{array}$ & 1288 & 804 & 264 & 64 & 786 & 2420 & 3.1 & Accepted & $2^{\text {nd }}$ & 0.06 & 0.0036 \\
\hline \multirow[t]{3}{*}{$\begin{array}{l}1 \\
0\end{array}$} & $\begin{array}{l}\text { Housing } \\
\text { characteristics }\end{array}$ & 1316 & 696 & 238 & 106 & 786 & 2356 & 3.0 & Accepted & $7^{\text {th }}$ & -0.04 & 0.0016 \\
\hline & Total & & & & & & & 30.4 & & & & 0.224 \\
\hline & & & & & & & & 3.04 & & & & \\
\hline
\end{tabular}

\subsection{Identification of the Resilience Level of the Different Communities}

Considering the various level of resilience to flood hazard as shown in table 6, it can be inferred that the respondents' perception on flood resilience in the study area with the highest mean of 3.3 is my household can find a safe place to evacuate to if there is an extreme flood event in the future and while the least of 1.8 is I have insured my farm and properties in the case of flood outbreak. However, factors higher than the criterion mean of 2.5 were ranked and categorised as either accepted or rejected. 
Table 6 Residents' agreement on Resilience level to flooding in the area

\begin{tabular}{|c|c|c|c|c|c|c|c|c|c|c|c|c|}
\hline \multirow[t]{2}{*}{$\mathbf{S} / \mathbf{N}$} & \multirow{2}{*}{$\begin{array}{ll}\text { Identification } & \text { of } \\
\text { Resilience Level to } & \text { Flooding }\end{array}$} & SA & A & D & SD & \multirow[t]{2}{*}{ Total } & \multirow[t]{2}{*}{ SWV } & \multirow[t]{2}{*}{ Mean } & \multirow[t]{2}{*}{ Remarks } & \multirow[t]{2}{*}{ Rank } & \multirow[t]{2}{*}{$\mathbf{x}-\mathbf{x}^{-}$} & \multirow[t]{2}{*}{$\left(x-x^{-}\right)^{2}$} \\
\hline & & 4 & 3 & 2 & 1 & & & & & & & \\
\hline 1 & $\begin{array}{l}\text { I can replace my home } \\
\text { quickly when it is affected } \\
\text { by flood }\end{array}$ & 1088 & 678 & 368 & 104 & 786 & 2238 & 2.8 & Accepted & $3^{\text {rd }}$ & 0.35 & 0.1225 \\
\hline 2 & $\begin{array}{l}\text { I have insured my farm and } \\
\text { properties in the case of } \\
\text { flood outbreak }\end{array}$ & 128 & 168 & 768 & 314 & 786 & 1378 & 1.8 & Rejected & $10^{\text {th }}$ & -0.65 & 0.4225 \\
\hline 3 & $\begin{array}{l}\text { My household can find a } \\
\text { safe place to evacuate to if } \\
\text { there is an extreme flood } \\
\text { event in the future }\end{array}$ & 1504 & 882 & 138 & 47 & 786 & 2571 & 3.3 & Accepted & $1^{\text {st }}$ & 0.85 & 0.7225 \\
\hline 4 & $\begin{array}{l}\text { I have learnt skill(s) to help } \\
\text { me cope with event of flood }\end{array}$ & 1152 & 921 & 196 & 93 & 786 & 2362 & 3.0 & Accepted & $2^{\text {nd }}$ & 0.55 & 0.3025 \\
\hline 5 & $\begin{array}{l}\text { I have constructed barriers } \\
\text { (levees, beams, floodwalls) } \\
\text { to stop floodwater from } \\
\text { entering your home. }\end{array}$ & 468 & 327 & 374 & 373 & 786 & 1542 & 2.0 & Rejected & $9^{\text {th }}$ & -0.45 & 0.2025 \\
\hline 6 & $\begin{array}{l}\text { I have sealed my walls in } \\
\text { basements with } \\
\text { waterproofing compounds } \\
\text { to avoid seepage. }\end{array}$ & 376 & 693 & 618 & 152 & 786 & 1839 & 2.3 & Rejected & $5^{\text {th }}$ & -0.15 & 0.0225 \\
\hline 7 & $\begin{array}{l}\text { I listen to the radio and } \\
\text { television for information } \\
\text { on flooding risk. }\end{array}$ & 492 & 456 & 470 & 276 & 786 & 1694 & 2.2 & Rejected & $7^{\text {th }}$ & -0.25 & 0.0625 \\
\hline 8 & $\begin{array}{l}\text { I avoid building in a } \\
\text { floodplain }\end{array}$ & 836 & 852 & 512 & 37 & 786 & 2237 & 2.8 & Accepted & $4^{\text {th }}$ & 0.35 & 0.1225 \\
\hline 9 & $\begin{array}{l}\text { I have an emergency plan } \\
\text { and practice survival skills, } \\
\text { like first aid and how to } \\
\text { disinfect water. }\end{array}$ & 388 & 456 & 542 & 266 & 786 & 1652 & 2.1 & Rejected & $8^{\text {th }}$ & -0.35 & 0.1225 \\
\hline 10 & $\begin{array}{l}\text { I turn off utilities at the } \\
\text { main switches or valves } \\
\text { and also disconnect } \\
\text { electrical appliances in the } \\
\text { event of flooding. }\end{array}$ & 516 & 282 & 728 & 199 & 786 & 1725 & 2.2 & Rejected & $6^{\text {th }}$ & -0.25 & 0.0625 \\
\hline & Total & & & & & & & 24.5 & & & & 2.165 \\
\hline & & & & & & & & 2.45 & & & & \\
\hline
\end{tabular}

\subsection{Coping Capacity of the Residents to Flooding}

From table 7, the highest mean is 3.1 while the least is 2.0 . However, the average mean is 2.9 . The range of effectiveness of flood control strategy in the event of flood disaster is 1.1. The control measure with high deviation above the mean include; raising of building foundation (3.1), construction of wooden bridges (3.0) and construction of levees by the River bans (2.9). These factors are considered to be effective in the study area in the control of flooding. 
Table 7 Residents' level of agreement on effectiveness of flood control strategy/coping capacity

\begin{tabular}{|c|c|c|c|c|c|c|c|c|c|c|c|c|}
\hline \multirow[t]{2}{*}{$\mathbf{S} / \mathbf{N}$} & \multirow{2}{*}{$\begin{array}{l}\text { Effectiveness of Flood } \\
\text { Control/Coping Capacity }\end{array}$} & SA & $\mathbf{A}$ & D & SD & \multirow[t]{2}{*}{ Total } & \multirow[t]{2}{*}{ SWV } & \multirow[t]{2}{*}{ Mean } & \multirow[t]{2}{*}{ Remarks } & \multirow[t]{2}{*}{ Rank } & \multirow[t]{2}{*}{$\mathbf{x}-\mathbf{x}^{-}$} & \multirow[t]{2}{*}{$\left(x-x^{-}\right)^{2}$} \\
\hline & & 4 & 3 & 2 & 1 & & & & & & & \\
\hline 1 & $\begin{array}{l}\text { Road reclamation using } \\
\text { sandbags and sawn dust }\end{array}$ & 840 & 1026 & 226 & 121 & 786 & 2213 & 2.8 & Accepted & $6^{\text {th }}$ & 0.2 & 0.04 \\
\hline 2 & $\begin{array}{l}\text { Construction of wooden } \\
\text { bridges }\end{array}$ & 1284 & 795 & 202 & 99 & 786 & 2381 & 3.0 & Accepted & $2^{\text {nd }}$ & 0.4 & 0.16 \\
\hline 3 & $\begin{array}{l}\text { Clearing blocked } \\
\text { drainages channels }\end{array}$ & 964 & 834 & 302 & 116 & 786 & 2216 & 2.8 & Accepted & $5^{\text {th }}$ & 0.2 & 0.04 \\
\hline 4 & $\begin{array}{l}\text { Periodic environmental } \\
\text { sanitation measures }\end{array}$ & 836 & 852 & 512 & 37 & 786 & 2237 & 2.8 & Accepted & $4^{\text {th }}$ & 0.2 & 0.04 \\
\hline 5 & Proper refuse disposal & 192 & 642 & 612 & 218 & 786 & 1564 & 2.0 & Rejected & $9^{\text {th }}$ & - & 0.36 \\
\hline 6 & $\begin{array}{l}\text { Raising of building } \\
\text { foundation }\end{array}$ & 1536 & 618) & 228 & 82 & 786 & 2464 & 3.1 & Accepted & $1^{\text {st }}$ & 0.5 & 0.25 \\
\hline 7 & $\begin{array}{l}\text { Construction of levees by } \\
\text { the River Bans }\end{array}$ & 944 & 723 & 572 & 23 & 786 & 2262 & 2.9 & Accepted & $3^{\text {rd }}$ & 0.3 & 0.09 \\
\hline 8 & $\begin{array}{l}\text { Building } \\
\text { platform/elevation above } \\
\text { flood level inside houses }\end{array}$ & 468 & 327 & 374 & 373 & 786 & 1542 & 2.0 & Rejected & $10^{\text {th }}$ & - & 0.36 \\
\hline 9 & $\begin{array}{l}\text { Clearing trash along water } \\
\text { ways }\end{array}$ & 692 & 372 & 492 & 243 & 786 & 1799 & 2.3 & Rejected & $8^{\text {th }}$ & - & 0.09 \\
\hline 10 & $\begin{array}{l}\text { Blockage/damming the } \\
\text { confluence between major } \\
\text { Rivers/Rivulets }\end{array}$ & 376 & 693 & 618 & 152 & 786 & 1839 & 2.3 & Rejected & $7^{\text {th }}$ & - & 0.09 \\
\hline & Total & & & & & & & 26.0 & & & & 1.52 \\
\hline & & & & & & & & 2.6 & & & & \\
\hline
\end{tabular}

\subsection{Influence/Effects of Flooding on Capacity Level of Residents}

Table 8 Residents' agreement index on the effects of flood disaster in the area

\begin{tabular}{|c|c|c|c|c|c|c|c|c|c|c|c|c|}
\hline \multirow[t]{2}{*}{$\mathbf{S} / \mathbf{N}$} & \multirow{2}{*}{$\begin{array}{l}\text { Severity of } \\
\text { Effects of Flood } \\
\text { Disaster }\end{array}$} & SA & $\mathbf{A}$ & D & SD & \multirow[t]{2}{*}{ Total } & \multirow[t]{2}{*}{ SWV } & \multirow[t]{2}{*}{ Mean } & \multirow[t]{2}{*}{ Remarks } & \multirow[t]{2}{*}{ Rank } & \multirow[t]{2}{*}{$\mathbf{x}-\mathbf{x}^{-}$} & \multirow[t]{2}{*}{$\left(x-x^{-}\right)^{2}$} \\
\hline & & 4 & 3 & 2 & 1 & & & & & & & \\
\hline 1 & Loss of life/injury & 328 & 468 & 462 & 317 & 786 & 1575 & 2.0 & Rejected & $10^{\text {th }}$ & -0.78 & 0.6084 \\
\hline 2 & Loss of livelihood & 1332 & 903 & 168 & 68 & 786 & 2471 & 3.1 & Accepted & $4^{\text {th }}$ & 0.32 & 0.1024 \\
\hline 3 & $\begin{array}{l}\text { Damage to } \\
\text { property }\end{array}$ & 1084 & 789 & 308 & 98 & 786 & 2279 & 2.9 & Accepted & $6^{\text {th }}$ & 0.12 & 0.0144 \\
\hline 4 & Displacement & 1176 & 756 & 278 & 101 & 786 & 2311 & 2.9 & Accepted & $5^{\text {th }}$ & 0.12 & 0.0144 \\
\hline 5 & $\begin{array}{l}\text { Outbreak of } \\
\text { disease }\end{array}$ & 492 & 456 & 470 & 276 & 786 & 1694 & 2.2 & Rejected & $8^{\text {th }}$ & -0.58 & 0.3364 \\
\hline 6 & Famine & 1636 & 885 & 68 & 48 & 786 & 2637 & 3.4 & Accepted & $1^{\text {st }}$ & 0.62 & 0.3844 \\
\hline 7 & $\begin{array}{l}\text { Loss of planting } \\
\text { materials }\end{array}$ & 388 & 456 & 542 & 266 & 786 & 1652 & 2.1 & Rejected & $9^{\text {th }}$ & -0.68 & 0.4624 \\
\hline
\end{tabular}


World Journal of Advanced Research and Reviews, 2021, 11(03), 009-022

\begin{tabular}{|l|l|c|c|c|c|c|c|c|c|c|c|c|}
\hline 8 & $\begin{array}{l}\text { Inflation of farm } \\
\text { produce }\end{array}$ & 1492 & 840 & 164 & 51 & 786 & 2547 & 3.2 & Accepted & $2^{\text {nd }}$ & 0.42 & 0.1764 \\
\hline 9 & $\begin{array}{l}\text { Damage to farm } \\
\text { land }\end{array}$ & 1084 & 645 & 298 & 151 & 786 & 2178 & 2.8 & Accepted & $7^{\text {th }}$ & 0.02 & 0.0004 \\
\hline 10 & Food loss & 1572 & 663 & 202 & 71 & 786 & 2508 & 3.2 & Accepted & $3^{\text {rd }}$ & 0.42 & 0.1764 \\
\hline & Total & & & & & & & 27.8 & & & & 2.276 \\
\hline & & & & & & & 2.78 & & & & \\
\hline
\end{tabular}

From table 8, its evident that residents' agreement index on the effects of flood disaster in the study area with the highest mean is 3.4 , while the least is 2.0. the average mean is 2.7. the range of the severity of the flood disaster variable is 1.4 . The control measure with high deviation above the mean include; famine (3.4), inflation of farm produce (3.2), food loss (3.2), loss of livelihood (3.1), displacement (2.9), damage to property (2.9) and damage to farm land (2.8). The effects with mean above the average mean value are considered to be very severe in the area.

\subsection{Organizational Support to Flood Hazards}

Several agencies and NGOs are in charge of different forms of support in event of emergencies. From table 9, it can be inferred that in the study area the highest mean is 2.2, while the least is 1.9 . The average mean is 2.05 . the range of the effectiveness of organizational support to flood disaster variable is 0.3 . Study shows that none of the parameter is above criterion mean hence where all rejected.

Table 9 Respondent's perception on organizational support

\begin{tabular}{|c|c|c|c|c|c|c|c|c|c|c|c|c|}
\hline \multirow[t]{2}{*}{$\mathbf{S} / \mathbf{N}$} & \multirow{2}{*}{$\begin{array}{l}\text { Respondent's } \\
\text { perception on } \\
\text { organizational } \\
\text { support }\end{array}$} & SA & $\mathbf{A}$ & D & SD & \multirow[t]{2}{*}{ Total } & \multirow[t]{2}{*}{ SWV } & \multirow[t]{2}{*}{ Mean } & \multirow[t]{2}{*}{ Remarks } & \multirow[t]{2}{*}{ Rank } & \multirow[t]{2}{*}{$\mathbf{x}-\mathbf{x}^{-}$} & \multirow[t]{2}{*}{$\left(x-x^{-}\right)^{2}$} \\
\hline & & 4 & 3 & 2 & 1 & & & & & & & \\
\hline 1 & $\begin{array}{l}\text { Emergency } \\
\text { shelter }\end{array}$ & 600 & 318) & 578 & 241 & 786 & 1737 & 2.2 & Rejected & $2^{\text {nd }}$ & 0.14 & 0.0196 \\
\hline 2 & $\begin{array}{l}\text { Public awareness } \\
\text { program }\end{array}$ & 279 & 345 & 614 & 271 & 786 & 1509 & 1.9 & Rejected & $9^{\text {th }}$ & -0.16 & 0.0256 \\
\hline 3 & $\begin{array}{l}\text { Emergency } \\
\text { management } \\
\text { plan }\end{array}$ & 328 & 384 & 584 & 284 & 786 & 1580 & 2.0 & Rejected & $6^{\text {th }}$ & -0.06 & 0.0036 \\
\hline 4 & $\begin{array}{l}\text { Early warning } \\
\text { system }\end{array}$ & 472 & 426 & 550 & 251 & 786 & 1699 & 2.2 & Rejected & $4^{\text {th }}$ & 0.14 & 0.0196 \\
\hline 5 & Flood insurance & 368 & 453 & 578 & 254 & 786 & 1653 & 2.1 & Rejected & $5^{\text {th }}$ & 0.04 & 0.0016 \\
\hline 6 & $\begin{array}{l}\text { Institutional } \\
\text { capacity }\end{array}$ & 216 & 336 & 682 & 279 & 786 & 1513 & 1.9 & Rejected & $8^{\text {th }}$ & -0.16 & 0.0256 \\
\hline 7 & $\begin{array}{l}\text { Search, rescue } \\
\text { and evacuation } \\
\text { plan }\end{array}$ & 624 & 417 & 454 & 264 & 786 & 1759 & 2.2 & Rejected & $1^{\text {st }}$ & 0.14 & 0.0196 \\
\hline 8 & $\begin{array}{l}\text { Development } \\
\text { control }\end{array}$ & 996 & 1041 & 258 & 61 & 786 & 1456 & 1.9 & Rejected & $10^{\text {th }}$ & -0.16 & 0.0256 \\
\hline 9 & Routine training & 136 & 582 & 570 & 273 & 786 & 1561 & 2.0 & Rejected & $7^{\text {th }}$ & -0.06 & 0.0036 \\
\hline 10 & Financial support & 516 & 282 & 728 & 199 & 786 & 1725 & 2.2 & Rejected & $3^{\text {rd }}$ & 0.14 & 0.0196 \\
\hline & Total & & & & & & & 20.6 & & & & 0.164 \\
\hline & & & & & & & & 2.06 & & & & \\
\hline
\end{tabular}




\section{Discussion of Findings}

The study revealed that $34.5 \%$ of the respondents are males while $65.5 \%$ are females as shown in table 2 . Study showed clearly that females were predominant across the study area. Women are particularly vulnerable to natural disasters compared to men because of their involvement in household tasks, such as collecting water and fuel wood, cooking, managing food, and providing child care. In all of these activities, women are at closest contact with the environment [14], [15]. They may also become victims of violence and face additional problems because of long-existing gender disparities [16]. This study agrees with [17] posited that women tend to recover more slowly than men from natural disasters and play a key role in the work of recovery after flood events. As primary care-givers women are more likely than men to have responsibility for dependants in the event of a flood and conversely are also more likely to be the sole adult householder. The gender division of labor critically determines women' s economic opportunities, constraints, incentives, and capacity and women's position in different sectors [18]. Low level of education is one of the main factors that deter women from equal participation in socioeconomic activities with their male counterparts. Poor parents consider any expenses for educating a girl unproductive as she leaves their family after marriage [19]. According [20], the literacy rate is 62 percent for males and 53 percent for females. In 2011, the rate of labor force participation was 84.3 percent for males and 57.2 percent for females [21] and the unemployment ratio of females to males is 7.4:4.2 [22]. Women's participation in economic activities remains unvalued at the national level because of the patriarchal structure, tradition, and norms. For example, more than three quarters of employed women of 15 years and above are found to be unpaid family laborers as opposed to less than one tenth who are self-employed and a few percentage contract workers [23]. Study also revealed that nearly all communities ravaged by flood has a high proximity to water body, low elevation, regular flood return period with a gig flood height ratio, lacks flood hazard information, high rainfall, high ratio of illiteracy, inadequate refuge dumping, poor drainage system to mention but a few. Absence of basic needs in the face of flood hazards such as water supply, electricity, food shortage, lack of planting materials as a result of inundation of flood, absence of storage facilities and poor accommodation has worsened the deployable pitiful situation. The study revealed that the assets of the respondents in the study area varied across several areas from Household Income (3.4), Water Resources (3.1), Number of Workforce (3.1), Number of Livestock (3.1), Agricultural Technical Capacity of Labourers (3.0), Cultivated Land Area (3.0), Housing Characteristics (3.0), Quality of Cultivated Land (3.0), Degree of Neighbourhood Communication (2.9) and Quality of Agricultural Tools (2.8). All the livelihood assets of the respondents were accepted as all its mean are above grand mean value. [24] stated that in Southern Nepal, flooding leads to large scale disruption of social and economic lives. The rivers bring large sediments whose deposition on agricultural lands harms productivity. The poor mostly live in these floodplains (vulnerable zones) because they have no opportunity to live in less hazardous areas. In Nepal, every year floods cause death, cultivated fields and irrigation, bridges and after rural infrastructure. He argues that policy makers, donors and relief and development agencies treat flood disaster as isolated events that break the continuity of the normal way of life. Most interventions to mitigate disasters are adhoc responses made under the assumption that an emergency support in the form of relief will help overcome the situation of hardship. Such support aims at restoring the situation to what it was before the disaster. Even when a flood disaster affects the same community every year, government, donors and non-governmental organizations respond by providing the same relief and rehabilitation measures each time. This approach does not consider the situation of a society during normal times between the occurrences of two hazard events. There are various measures that have been employed in the control of flood in the area. Among these measures include raising of building foundation, construction of wooden bridges, construction of levees by the river bans, periodic environmental sanitation measures among others. But the constant experience of flood in the study area has been very enormous in the recent time as if no action has been taken in the community. The effectiveness of the of flood control within the study area is explained using Likert's scale. From table 7, the highest mean is 3.1 while the least is 2.0. However, the average mean is 2.9. The range of effectiveness of flood control strategy in the event of flood disaster is 1.1. The control measure with high deviation above the mean include; raising of building foundation (3.1), construction of wooden bridges (3.0) and construction of levees by the River bans (2.9). These factors are considered to be effective in the study area in the control of flooding. However, effects higher than the criterion of 2.5 where accepted and ranked accordingly while those below where rejected. [25] states that flood disaster has different impact on individuals, households and communities. People cope in different ways. Those who have the capacity after being hit by a disaster emerge faster while those without such capacity sink deeper into the spiral of impoverishment. Coping strategies include actions such as migration from floods affected areas, flood forecasting, flood insurance of animals and crops, food stockpiling, providing emergency health services and building flood shelters. They have, however, not been woven systematically into the approach to achieve security from flooding. If the approaches build on coping strategies and seek to identify new ones, they could address the social impacts of flood problems affectively at a lower social, economic and environmental cost than approaches that attempt to manage or control the resource base itself [24]. [25] give vivid view on how structural and non-structural measures could curb the menace of floods. The structural measures such as check dams, levees, flood walls and adequate drainage systems will help control periodic inundation in the areas that are liable to flooding in the following ways: The construction of structures for irrigation and the use of excess run-off water for inter-basin transfer as an alternative to 
absorb excess water from the Cameroons; Check dams will reduce peak flows; Levees and flood walls confines flow within predetermined channels; Adequate drainage systems will reduce peak flow stages of flood and divert excessive flow; In communities where the rate of flow of storm water is high, embankments should be constructed to breakdown storm water so as not to result into floods [26]. From the Table 8, it can be inferred that the severity of the effects of flood disaster in the study area with the highest mean is 3.4, while the least is 2.0. The average mean is 2.7 . The range of severity of the effects of flood disaster index (SFI) variables is 1.4. The effects with mean above the average mean value are considered to be very severe in the area while those below the average mean are considered no so severe in the area. Effects with high severity of flooding index (EFI) are famine, inflation of farm produce, food loss, loss of livelihood, displacement, damage to property and damage to farm land with 3.4, 3.2, 3.2, 3.1, $2.9,2.9$ and 2.8 . respectively. The least mean of the effects of flood is 2.0 which stands for loss of lives/injury in the study area. Though, loss of lives as effects of flood has the least mean of severity statistically from the perceptions of the respondents, but is the greatest loss as it is the only effect of flood that is irreplaceable.

A study by [27] suggest that floods are the most taxing of water related natural disasters to humans, material assets as well as to cultural and ecological resources affecting people and their livelihoods and claiming thousands of lives annually worldwide. According to the Australian experience, the emotional behaviour of many flood victims was shocking. The emotional cost of flooding was long lived. Follow-up studies found that about one-quarter still had not recovered from the emotional trauma of the event. Factors that contributed to the non-recovery included the severity of the flooding, the degree of the resulting financial hardship, age and socio-economic status. Elderly people on low incomes whose houses were deeply flooded were the most ill- affected [28].

NGOs are organizations that are non-profit making, voluntary and independent of government, engaged in activities concerning various societal and developmental issues. The role of the NGO's during a disaster is to have quick response and to try and save as many lives as it can with the given resources. NGO's have a faster response to situations because it does not need to clear paperwork. Study on the different NGOs in charge of different supports in event of emergencies as shown in the study area varied a crossed the across. The highest mean is 2.2 while the least is 1.9 . Study reveals that mean of all the items are below the grand mean hence all the items were rejected. NGO is a legally constituted, voluntary association of individuals or groups that is neither a government agency nor profit enterprise. It is a private organisation that pursues activities to relieve suffering, promote the interests of the poor, protect the environment, provide basic social services, and/or understand community development [29]. Based on the findings of this study, it revealed that though NGOs may be aware and knowledgeable about flooding and have include it in their program and as such yet to reach their clients /beneficiaries with information related to it. The NGOs are acts as facilitators to emergencies and serves as succour to the plight of the vulnerable.

\section{Conclusion}

Farming is a significant part of the study area as over $48.9 \%$ of the respondents depends on farming as its livelihood assets. Most of the villagers are directly and indirectly dependent on the agricultural lands and cultivate for their livelihood. Nonetheless, the preeminent role of agriculture in reducing vulnerability to floods has not shifted significantly. Daily survival of these people is highly dependent on agricultural lands and other informal sources of livelihoods. Therefore, impact of disaster is not only dependent on access to sources of livelihoods but also on the level of dependency on these sources of livelihoods. Obviously, this destruction had negative effects on the livelihoods of the people with grave implication on their financial and health status. However, the people are not deterred as majority of those interviewed declined to vacate/relocate from the area after the 2012 flood disaster despite the high vulnerability of the area to floods. However, the understanding of the vulnerability of the area to flooding was instrumental in the peoples' choice to live with the floods, and by extension the need to grow resilience. Respondents' agreement on resilience level to flooding in the study area include: my household can find a safe place to evacuate to if there is an extreme flood event in the future, I have learnt skill(s) to help me cope with event of flood, I can replace my home quickly when it is affected by flood and I have insured my farm and properties in the case of flood outbreak. This resilience of the people its firm on her belief that their tradition forbids them from relocating from the area, hence flood warning issued by government for relocation prior to flooding may not be heeded by the people.

The study also revealed that the following measures were considered effective in control, management and coping capacity of flood: raising of building foundation, construction of wooden bridges, periodic environmental sanitation measures, road reclamation using sandbags and sawn dust, clearing blocked drainages channels and proper refuse disposals. Study also revealed that members of the communities have tried their best in controlling or avoiding flood occurrences through various community projects like drainage and clearing of water ways in the community. However, major projects like dredging of river, construction of drainages and bridges where necessary and proper adherence to planning regulations are expected from government for implementation. However, residents' agreement on the severity 
of effects of flood disaster in the study area include loss of livelihood, displacement, damage to property, outbreak of disease and loss of life/injury. The study recommended that creation of awareness among people living in disasterprone areas of the risk they face and how best to respond when it occurs can be done to enhance local people's confidence and empower them to act when faced with danger; there should be policies that target the marginalized in society, such as women, children, elderly, or the poor otherwise these groups will remain most vulnerable; the people must be empowered to improve on their level of resilience to flooding, respond effectively and contribute to the development of their own communities on a sustained basis; and successful flood risk management should therefore be dependent upon the active support of all on whom the effects of flooding may impact, those directly at risk, the civil authorities and the wider community.

\section{Compliance with ethical standards}

\section{Acknowledgments}

We acknowledge the support of the community chiefs for given us access to their various communities during data gathering. We also acknowledge the support and cooperation of our respondents.

\section{Disclosure of conflict of interest}

There is not conflict of interest among the authors in this paper.

\section{Statement of informed consent}

Informed consent was obtained from all individual participants included in this study.

\section{References}

[1] Nigeria Meteorological Agency (NIMET) 2013 Rainfall Prediction, Daily Trust, March 11th, 2013

[2] Herath S, Y Wang. Incorporating wind damage in potential flood loss estimation. Global Environmental Research. 2009.

[3] Dutta D, W Wright, K Nakayama, Y Sugawara. Design of synthetic impact response functions for flood vulnerability assessment under climate change conditions: Case studies in two selected coastal zones in Australia and Japan. Natural Hazards Rev. 2013; 14: 52-65

[4] NEMA (Nigerian Emergency Manageent Agency). Report on flood disasters in Nigeria. Abuja: Government Press. 2013.

[5] Benson C. Macro-economic Concepts of Vulnerability: Dynamics, Complexity and Public Policy, in G. Bankoff, G. Frerks and D. Hilhorst, eds, Mapping Vulnerability: Disasters, Development and People, London: Earthscan. 2004.

[6] Wisner BP, Blaikie T, Cannon D. At Risk: Natural Hazards. People's Vulnerability, and Disasters, 2nd edn, London: Routledge. 2004

[7] Tanner T, D Lewis, D Wrathall, R Bronen, N Cradock-Henry, S Huq, MA Rahman. Livelihood Resilience in the Face of Climate Change. Nature Climate Change. 2015; 5(1).

[8] FAO. UN joint programmes. Integrating gender issues in food security, agriculture and rural development. 2010

[9] FAO, ILO. The Livelihood Assessment Tool-Kit, 2009

[10] FAO. FAO in emergencies, 2009

[11] Aderogba KA. Qualitative studies of recent floods and sustainable growth and development of cities and towns in Nigeria. Int. J. Basic Applied Sci. 2012; 1: 200-216.

[12] UN-ISDR - International Strategy for Disaster Reduction: Hyogo Framework for Action 2005-2015: Building the Resilience of Nations and Communities to Disasters, World Conference on Disaster Reduction, 18-22 January 2005, Kobe, Hyogo, Japan, 2005.

[13] Nigeria Meteorological Agency NIMET (2013) 2013 Rainfall Prediction, Daily Trust, March 11 th 2013 
[14] Mysiak, J., Testella, F., Bonaiuto, M., Carrus, G., De Dominicis, S., Ganucci Cancellieri, U., Firus, K., and Grifoni, P.: Flood risk management in Italy: challenges and opportunities for the implementation of the EU Floods Directive (2007/60/EC), Nat. Hazards Earth Syst. Sci., 13, 2883-2890,2013. doi:10.5194/nhess-132883-2013, 2013

[15] World Bank. Natural Disasters: Eluding Nature's Wrath, mimeo. 2004.

[16] Nasiri H,Yusof M. J. M. and Ali T. A. M (2016) An overview to flood vulnerability assessment methods, Sustain. Water Resour. Manag. 2016. DOI 10.1007/s40899-016-0051-X

[17] Nkeki, F.N., P.J. Henah and V.N. Ojeh. Geospatial techniques for the assessment and analysis of flood risk along the Niger-Benue Basin in Nigeria. J. Geographic Inform. Syst., 5: 123-135. 2013. DOI: 10.4236/jgis.2013.5. 2013

[18] Ajibade, I., G. McBean and R. Bezner-Kerr. Urban flooding in Lagos, Nigeria: Patterns of vulnerability and resilience among women. Global Environ. Change, 23: 1714-1725. 2013. DOI: 10.1016/j.gloenvcha.2013.08.009

[19] Barredo JI, Demicheli L. “Urban Sustainability in Developing Countries' Megacities: Modelling and Predicting Future Urban growth in Lagos". Cities 20(5): 297-310.2003

[20] Amadi L. Climate change, peasantry and rural food production decline in the Niger Delta Region: A case of the 2012 flood disaster. Journal of Agricultural and Crop Research Vol. 1(6), pp. 94-103, December 2013 ISSN: $2384-$ 731X Research Paper

[21] Alkire, S., \& Maria, E. S. Acute Multidimensional Poverty: A New Index for Developing Countries, vol. 138, UNDP Human Development Research Paper, New York, USA, 2010. UNDP.

[22] Gardner, J. A. and Dekens, J.: Mountain hazards and the resilience of social-ecological systems: lessons learned in India and Canada, Nat. Hazards, 41, 317-336, 2007.

[23] Hannan, C. Mainstreaming Gender Perspectives in Environmental Management and Mitigation of Natural Disasters. Presented at the Roundtable Panel and Discussion organized by The United Nations Division for the Advancement of Women and The NGO Committee on the Status of Women in preparation for the 46th Session of the Commission on the Status of Women On Disproportionate Impact of Natural Disasters on Women 17 January 2002

[24] ICSU (International Council for Science). A Science Plan for Integrated Research on Disaster Risk: Addressing the Challenge of Natural and Human-Induced Environmental Hazards. Paris, France: ICSU. 66 p. 2008.

[25] Ikusemoran, M., D. Anthony and U.M. Maryah. GIS based assessment of flood risk and vulnerability of communities in the Benue floodplains, Adamawa State, Nigeria. J. Geography Geol., 5: 148-160. 2013. D0I: 10.5539/jgg.v5n4p148

[26] IPCC (Intergovernmental Panel on Climate Change). Climate Change Impacts, Adaptation and Vulnerability, Contribution of Working Group II to the Fourth Assessment Report of the Intergovernmental Panel on Climate Change Assessment Report, Summary for Policymakers, 2007. Available at http://www.ipcc.ch/pdf/assessmentreport/ar4/wg2/ar4-wg2-spm.pdf

[27] Meyer, V., Kuhlicke, C., Luther, J., Fuchs, S., Priest, S., Dorner, W., Serrhini, K., Pardoe, J., McCarthy, S., Seidel, J., Palka, G., Unnerstall, H., Viavattene, C., and Scheuer, S.: Recommendations for the user-specific enhancement of flood maps, Nat. Hazards Earth Syst. Sci., 12, 1701-1716, doi:10.5194/nhess-121701-2012, 2012.

[28] UN-International Strategy for Disaster Reduction (UN-ISDR). “Disaster Risk Reduction Strategies and Risk Management Practices: Critical Elements for Adaptation to Climate Change" Submission to the UNFCCC Adhoc Working Group on Long Term Cooperative Action, 2008. Available at: www.unisdr.org/.../riskreduction/climatechange/.../IASC-ISDR_paper_cc_and_DDR.pdf (Accessed 16 Oct. 2011).

[29] United Nations International Strategy for Disaster Reduction. In HFA-Asia Pacific, 2011-2013, Hyogo Framework for Action in Asia and the Pacific; UNISDR: Geneva, Switzerland. 